\title{
INFLUENCE OF ANAESTHESIA AND SURGERY ON NEUTROPHIL CHEMOTAXIS
}

\author{
G.C. Moudgil, A.R. PANDYa AND D.J. Ludlow
}

\begin{abstract}
Chemotactic migration of leucocytes is one of the earliest and essential events among the host defense mechanisms against infection. Therefore, the influence of anaesthesia and surgery on leucocyte chemotaxis was investigated in patients requiring elective surgery. The chemotactic migration of peripheral blood leucocytes was measured by a modification of Boyden's method immediately before and after operation and on the second and third postoperative days. In addition, the influence of exposure to different molar concentrations of thiopentone on chemotactic migration was investigated in vitro. A statistically significant inhibition of leucocyte chemotactic migration was observed in the immediate postoperative period. ( $P<$ 0.05 ). However, this inhibition was of short duration and chemotactic activity returned to normal on the day after operation under general anaesthesia. Exposure to thiopentone produced a significant and dose dependent inhibition of chemotactic migration in vitro. It is concluded that surgery under general anaesthesia and exposure to thiopentone in vitro produce a significant though reversible inhibition of chemotactic migration of leucocytes.
\end{abstract}

KEY WORDS: BLOOD, leucocytes, chemotaxis with anaesthesia, \& surgery.

THE MIGRATION of granulocytes, mononuclear phagocytes, and lymphocytes is one of the earliest events following tissue damage or infection from pathogenic organisms. The direction of this migration is controlled by chemical mediators released at and diffusing from the site of injury or infection. Any depression of this directional locomotion is likely to allow the invading organisms to become established in the tissues and thus enhance the incidence of infection. Since anaesthesia plays a major part in the surgical intervention, it is important that the role of anaesthesia, if any, in the pathogenesis of infection following surgery, be clearly defined.

A decrease in random non-directional locomotion under the influence of inhalational anaesthetic agents has been observed in a wide range of cell species. Nunn, et $a l^{1,2}$ have reported a reversible dose dependent inhibition of tetrahymena pyriformis and human lymphocytes on exposure to halothane. Similarly Bruce $^{3}$ observed that halothane decreased the mobilization of neutrophils in mice in response to intraperitoneal injection of pseudomonas endotoxin. However,

*G.C. Moudgil, M.B., B.S., M.Sc., F.F.A.R.C.S., Assistant Professor; A.R. Pandya, M.D., Resident; D.J. Ludlow, B.Sc.. Research Assistant; Department of Anaesthesia, Memorial University, St. John's, Newfoundland.

Dr. Moudgil's present address is: Department of Anaesthesia, McMaster University, 1200 Main Street W., Hamilton, Ontario. Canada, L8N 3ZS

Canad. Anaesth. Soc. J., vol. 28, no. 3, May 1981 there is a diversity of opinion regarding chemotactic locomotion in vivo and in vitro. A dose dependent inhibition of leucocyte locomotion was reported by Moudgil et al, ${ }^{4}$ under the influence of local, intravenous, and inhalational anaesthetic agents in vitro. More recently, Mathieu, et $a l .^{5}$ have also reported an inhibition of leucocyte locomotion by intravenous anaesthetic agents in vitro. A similar inhibition of leucocyte migration was reported by Stanley, et al. ${ }^{6}$ in patients following surgery under general anaesthesia. In contrast, Duncan and Cullen ${ }^{7}$ and Nunn, et $a l,{ }^{8}$ did not detect any depression of leucocyte chemotaxis by thiopentone and halothane in vitro. In order to clarify these contradictory findings, the overall effects of anaesthesia and surgery on the leucocyte chemotaxis has been investigated immediately before and up to two days after operation. The influence of adding different concentrations of thiopentone to the cell preparations in vitro has also been assessed.

\section{Materials and Methods}

\section{Leucocyte Chemotaxis After Anaesthesia and Surgery.}

After giving informed consent, 30 adult patients awaiting elective surgery for plastic, orthopedic, and neurosurgical procedures were investigated. The age of the patients, body weight, and duration of operation are shown in Table I. Patients with pre-existing infection, on 
TABLE I

Peri-Operative Data

\begin{tabular}{lc}
\hline & Mean \pm S.D. \\
\hline Number of Patients & 30 \\
Age (years) & $40.30 \pm 17.56$ \\
Body Weight (kg) & $68.40 \pm 9.58$ \\
Duration of Operation (min) & $149.17 \pm 62.85$ \\
Total WBC $\left(\mathrm{mm}^{3}\right)$ Preop & $7953 \pm 2030$ \\
l Day Postop & $9858 \pm 2782$ \\
\hline
\end{tabular}

antibiotic therapy, or likely to require blood transfusion were excluded from the study. Differing anaesthetic agents and techniques were used intentionally in order to assess the overall effects of clinical anaesthesia and surgery on the leucocyte chemotactic function in the perioperative period.

Patients were premedicated with diazepam (10-15 mg orally), or morphine (10-15 mg intramuscularly), 90 minutes before operation. Anaesthesia was induced with thiopentone $\left(3-5 \mathrm{mg} \cdot \mathrm{kg}^{-1}\right)$ and tracheal intubation was facilitated by the use of suxamethonium $\left(1.0 \mathrm{mg} \cdot \mathrm{kg}^{-1}\right)$. Anaesthesia was maintained with enflurane (1-4 per cent) or halothane $(0.5-2.0$ per cent) with nitrous oxide and oxygen (70:30). All patients were ventilated after administration of d-tubocurarine or pancuronium. During operation the patients were infused with lactated Ringer's solution $(5-10 \mathrm{ml}$. $\left.\mathrm{kg}^{-1} \cdot \mathrm{hr}^{-1}\right)$. Thus a wide range of anaesthetic agents were used to cover the spectrum of clinical anaesthesia.

Heparinized peripheral venous blood samples $(20 \mathrm{ml})$ were obtained at the following times: a) before induction but after premedication, b) after completion of the operation, c) one and two days postoperatively.

All blood samples were obtained at the same time of the day on each occasion in order to avoid the influence of any diurnal variation on leucocyte function. In order to assess the effect of surgery on the white cell population, total leucocyte counts were made preoperatively and the day after.

Leucocytes were separated from the whole blood by adding $1 \mathrm{ml}$ of dextran 110 to facilitate erythrocyte sedimentation at room temperature. After one hour the cell-rich supernatant plasma was aspirated and centrifuged at $400 \mathrm{~g}$ for 10 minutes. The leucocyte pellet obtained was washed twice in Gey's balanced salt solution at $\mathrm{pH} 7.2$ and resuspended in it to give a final count of approximately $10^{6}$ cells $/ \mathrm{ml}$. The cell viability was ascertained by Trypan blue 'Dye exclusion

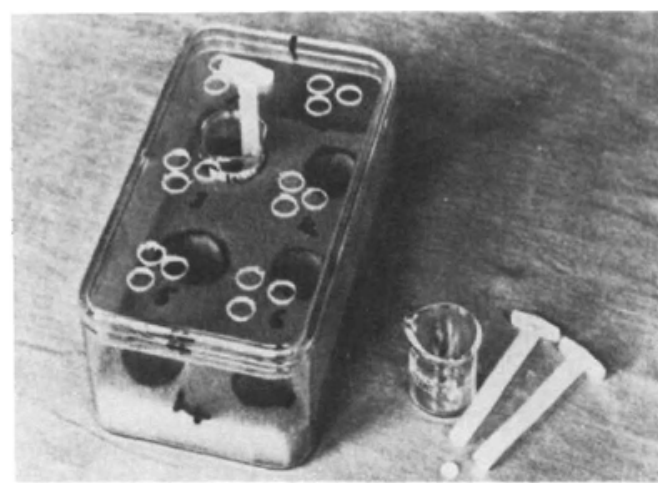

FIGURE 1 The apparatus used to measure leucocyte locomotion. The upper chamber consists of a tuberculin syringe barrel with a micropore filter glued to the lower end. This upper chamber contains the cells and is suspended through the lid of the sandwich box into the lower chamber, a $5 \mathrm{ml}$ beaker, which contains the chemoattractant, casein.

test'. The chemotactic migration of these leucocytes was measured in response to $0,2,3$, and 4 $\mathrm{mg} / \mathrm{ml}$ of chemo-attractant casein (Sigma, St. Louis) at different time intervals as specified earlier.

A modification of Boyden's method as described previously was used to measure the chemotactic migration. The cells were placed above a micropore filter with pore size $3 \mu$ (Millipore, Bedford, Mass.) attached to the lower end of a sawn off tuberculin syringe. The lower chambers contained different concentrations of casein ranging from 0 to $4 \mathrm{mg} / \mathrm{ml}$, in Gey's balanced salt solution. Thus a gradient was established between the cells above and the chemotactic agent below the filter (Figure 1). A minimum of two chambers were used at each concentration of casein for determination of chemotactic migration. All tests were incubated at $37^{\circ}$ for 90 minutes to allow cell migration. The cell migration was halted by fixation in ethanol and the filters were stained with haematoxylin using a standard technique. The filters were rendered transparent by immersion in xylene for $10 \mathrm{~min}$ utes. The filters were mounted on a slide and examined under the oil immersion lens of the microscope. The 'leading front' of the migrating cells was visualized by the fine adjustment. The cell migration from the filter top was calculated by determining the distance migrated by the "leading front' of the cells through the micropore filter towards the gradient of chemotactic agent casein. The mean of five readings of 'cell fronts' was calculated on each filter. The difference in migration between the unstimulated control cells and the 
cells stimulated for migration with different concentrations of casein $(2 \mathrm{mg}, 3 \mathrm{mg}$, and $4 \mathrm{mg} / \mathrm{ml}$ ) was recorded as relative migration-(stimulated migration/unstimulated migration).

Significance of the difference in relative chemotactic migration in response to various concentrations of casein at different time intervals in relation to surgery was tested by Analysis of Variance. The residual mean squares were tested with maximum F-ratio at 95 per cent confidence. The mean values at all 'times' (in relation to anaesthesia and operation) and all doses of casein were compared by using Tukey's W multiple comparison procedure.

\section{Effect Of Thiopentone On Chemotaxis in Vitro}

In 8 of the 30 patients, peripheral venous blood samples were obtained before premedication. These patients did not have any systemic disease and they were not taking any medication. The leucocytes were separated from the whole blood as described above and were exposed in vitro to varying concentrations of thiopentone ranging from $10^{-3}$ to $10^{-3}$ Molar. The cell viability was ascertained after exposure to different concentrations of thiopentone by Trypan blue 'dye exclusion test'. The concentrations of thiopentone both above and below the filter were kept identical so that there was no gradient of the drug across the filter. The influence of thiopentone on chemotactic migration was measured in response to only one concentration of casein $(3 \mathrm{mg} / \mathrm{ml})$ in all tests. In the control tests, casein or the drug or both were omitted. The significance of the difference in migration between the control tests, tests with casein, and those with casein and thiopentone was calculated by Student's ' $t$ ' test.

\section{RESUlts}

\section{Effects of Anaesthesia and Surgery on Chemotaxis}

Leucocyte locomotion in control preparations (random locomotion in the absence of any chemotactic stimulus) differed from patient to patient, this being representative of each patient's innate leucocyte activity. Although the mean total leucocyte counts were higher one day after operation, this did not affect the mean range of the random locomotion at different time intervals in relation to anaesthesia and surgery. However, on stimulation for migration with casein, leucocytes from all patients, at different time intervals tested, elicited a classical dose response curve for casein. The chemotactic migration increased at low concentration of casein $(2 \mathrm{mg} / \mathrm{ml})$, reaching a peak at $3 \mathrm{mg} / \mathrm{ml}$ and then declined at higher concentration of casein $(4 \mathrm{mg} / \mathrm{ml})$ (Table II).

The chemotactic activity of leucocytes obtained before operation, immediately after and one and two days after operation, when analysed by analysis of variance, revealed that although the different concentrations of casein were able to stimulate the chemotactic migration at all time intervals, yet this response was significantly altered at different time intervals.

The difference in migration at different time intervals in relation to preoperative chemotactic activity when analysed by Tukey's $W$ analysis showed a statistically significant inhibition of leucocyte chemotaxis in the immediate postoperative period in response to all concentrations of casein $(p<0.05)$. The 95 per cent confidence interval (based on Tukey's W procedure) about 3 $\mathrm{mg} / \mathrm{ml}$ concentration of casein at different times as illustrated in Figure 2 showed that relative migration (stimulated migration/unstimulated migration) was highest for casein $(3 \mathrm{mg} / \mathrm{ml})$ at all time intervals. However, in the immediate postoperative period anaesthesia and surgery resulted in a significant depression of the chemotactic migration. A similar depression was also cibserved in relation to $2 \mathrm{mg} / \mathrm{ml}$ and $4 \mathrm{mg} / \mathrm{ml}$ concentrations of casein in the immediate postoperative period. Although this inhibition of leucocyte locomotion persisted in 50 per cent of patients up to the third postoperative day, this was not statistically significant when compared with the preoperative period.

These results indicate that anaesthesia and surgery depress the leucocyte chemotactic migration in the immediate postoperative period. However, this depression of chemotactic migration was transient and reversible.

\section{Influence of Thiopentone on Leucocyte \\ Chemotaxis In Vitro}

In leucocyte preparations, where thiopentone $\left(10^{-3}\right.$ Molar to $10^{-6}$ Molar $)$ had been added to the cell preparations in vitro, a significant dose dependent inhibition of leucocyte migration towards casein was observed in all cases ( $p<$ 0.005 ) (Figure 3). This inhibition of chemotactic migration was also observed at serum thiopentone concentrations commonly achieved following clinical anaesthesia $\left(5.7 \times 10^{-5} \mathrm{M}\right)($ Table 11$)$.

These observations indicate that the overall effects of anaesthesia and surgery in vivo, and the effects of thiopentone in vitro, cause a depression of human leucocyte chemotaxis. The depression 
TABLE II

Human Random Leucocyte locomotion (Control) and Chemotactic Locomotion in Response to Different Concentrations of Casein

\begin{tabular}{|c|c|c|c|}
\hline \multirow[b]{2}{*}{$\begin{array}{c}\text { Control } \\
\text { Mean } \pm \text { S.E. }\end{array}$} & \multicolumn{3}{|c|}{ Leucocyte Locomotion $(\mu \mathrm{m})$ towards Casein } \\
\hline & $\begin{array}{c}2 \mathrm{mg} / \mathrm{ml} \\
\text { Mean } \pm \text { S.E. }\end{array}$ & $\begin{array}{c}3 \mathrm{mg} / \mathrm{ml} \\
\text { Mean } \pm \text { S.E. }\end{array}$ & $\begin{array}{c}4 \mathrm{mg} / \mathrm{ml} \\
\text { Mean } \pm \text { S.E. }\end{array}$ \\
\hline $52.2 \pm 0.65$ & $64.8 \pm 0.79$ & $70.4 \pm 0.67$ & $63.9 \pm 0.75$ \\
\hline $70.4 \pm 0.45$ & $79.5 \pm 0.40$ & $83.0 \pm 0.59$ & $77.6 \pm 0.67$ \\
\hline $67.8 \pm 0.72$ & $84.1 \pm 0.78$ & $87.0 \pm 0.58$ & $81.7 \pm 0.90$ \\
\hline $61.8 \pm 0.79$ & $70.0 \pm 0.45$ & $74.5 \pm 0.52$ & $75.6 \pm 1.07$ \\
\hline $50.1 \pm 0.50$ & $80.6 \pm 0.58$ & $87.0 \pm 0.58$ & $78.7 \pm 0.72$ \\
\hline $62.6 \pm 0.82$ & $72.9 \pm 1.01$ & $84.0 \pm 0.75$ & $74.0 \pm 0.68$ \\
\hline $64.5 \pm 0.84$ & $78.0 \pm 1.02$ & $82.3 \pm 0.67$ & $73.9 \pm 0.78$ \\
\hline $73.1 \pm 0.91$ & $79.0 \pm 0.71$ & $75.0 \pm 0.42$ & $80.3 \pm 0.62$ \\
\hline $45.4 \pm 0.64$ & $59.2 \pm 0.39$ & $61.3 \pm 0.45$ & $58.5 \pm 0.49$ \\
\hline $61.1 \pm 0.69$ & $76.1 \pm 0.72$ & $82.7 \pm 0.94$ & $72.1 \pm 0.59$ \\
\hline $72.6 \pm 0.96$ & $83.0 \pm 0.80$ & $87.6 \pm 1.17$ & $78.7 \pm 0.97$ \\
\hline $51.1 \pm 0.41$ & $63.1 \pm 0.53$ & $65.6 \pm 0.40$ & $61.9 \pm 0.48$ \\
\hline $43.3 \pm 0.84$ & $59.8 \pm 0.66$ & $68.6 \pm 0.55$ & $63.9 \pm 0.46$ \\
\hline $43.1 \pm 0.66$ & $57.8 \pm 0.84$ & $60.9 \pm 0.74$ & $60.9 \pm 0.50$ \\
\hline $66.9 \pm 0.86$ & $75.6 \pm 0.56$ & $73.6 \pm 0.78$ & $72.0 \pm 0.63$ \\
\hline $26.9 \pm 0.96$ & $31.7 \pm 0.91$ & $33.6 \pm 0.90$ & $35.7 \pm 0.96$ \\
\hline $67.3 \pm 0.79$ & $77.7 \pm 0.80$ & $80.2 \pm 0.42$ & $77.3 \pm 0.70$ \\
\hline $51.1 \pm 0.67$ & $62.7 \pm 0.72$ & $65.7 \pm 0.65$ & $60.5 \pm 0.81$ \\
\hline $66.6 \pm 0.85$ & $72.2 \pm 0.66$ & $80.3 \pm 0.93$ & $74.4 \pm 0.76$ \\
\hline $32.1 \pm 0.78$ & $55.6 \pm 0.52$ & $62.0 \pm 0.61$ & $55.5 \pm 0.69$ \\
\hline $42.3 \pm 0.62$ & $61.6 \pm 0.54$ & $66.5 \pm 0.60$ & $65.2 \pm 0.62$ \\
\hline $32.0 \pm 0.59$ & $54.1 \pm 0.79$ & $69.8 \pm 0.35$ & $56.0 \pm 0.65$ \\
\hline
\end{tabular}

RATIO OF MIGRATION TO CASEIN AT DIFFERENT IIMES

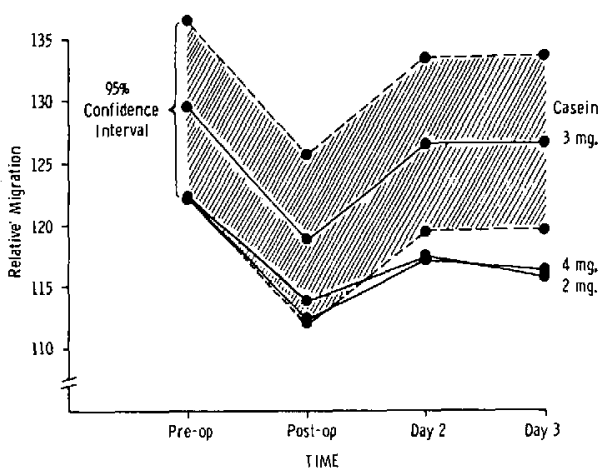

Figure 2 The 95 per cent confidence interval of relative chemotactic migration (based on Tukey W procedurs) about $3 \mathrm{mg} / \mathrm{ml}$ concentration of casein at different time intervals. The 95 per cent confidence limits around casein $2 \mathrm{mg} / \mathrm{ml}$ and $4 \mathrm{mg} / \mathrm{ml}$, though identical, have not been plotted in this figure.

of chemotactic migration following surgery and anaesthesia, however, was short lived and the leucocyte migratory activity returned to the preoperative levels on the day after surgery.

\section{Discussion}

Among body defenses against infection, an intact leucocyte function is of fundamental importance. While a wide variety of factors can be included in the pathogenesis of infection following surgery - such as age, sex, race, nutrition, duration, urgency and time of operation, the accumulation of fluid and secretions, immobilization in bed, drug therapy, metabolic and electrolyte disturbances - in the ultimate analysis it is a depression of body defenses which allows the invading infection to become established.

The present study has demonstrated that surgery under general anaesthesia, using a wide range of anaesthetic agents, causes a depression of chemically stimulated leucocyte migration. This depression of chemotactic migration, however, was short lived and transient, and the leucocyte locomotion returned to normal on the first postoperative day.

The aim of the present study was to investigate the overall effects of clinical anaesthesia and surgery on the leucocyte chemotaxis, therefore, neither the anaesthetic agents nor the anaesthetic techniques were restricted. The effects observed 
LEUCOMTE LOCOMOTION INHIBITION BY IHIOPEMTONE IIn Vitrol

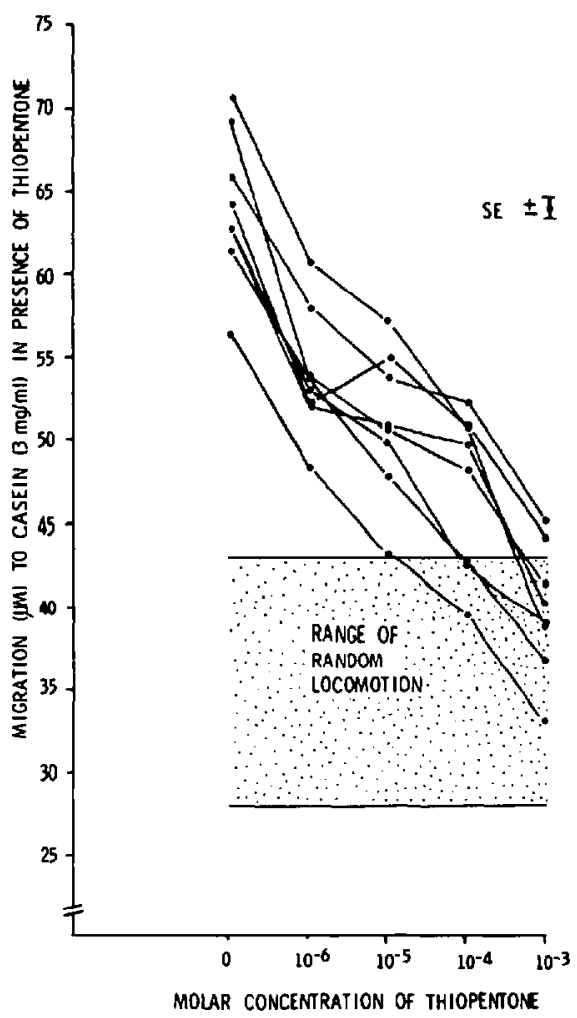

FIGURE 3 Effects of thiopentone on human leucocyte locomotion towards casein in eight patients.

in the present study represent an overall combined influence of clinical anaesthesia and surgery, rather than the effect of a specific anaesthetic agent on the chemotactic migration. Although the response to casein would appear to be alinear, chemotaxis being greater with $3 \mathrm{mg} / \mathrm{ml}$ than with either 2 or $4 \mathrm{mg} / \mathrm{ml}$ (Figure 2), yet it is consistant with the classical dose response curve for casein. It is not clear why, when the absolute concentration of the chemotactic substance exceeds a given figure, the distance travelled by the cells in its presence decreases. It is possible that at high concentrations of the chemotactic agent the receptors on the cells become fully saturated, or the metabolic systems necessary for migration become exhausted.

The inhibition of chemotactic migration observed in this study is in accord with the earlier observations of Stanley, et al $;^{6}$ however, it differs from the in vitro observation of Duncan and Cullen ${ }^{7}$ and Nun, et al $^{8}$ In their study, Stanley, et al. observed that leucocyte chemotactic function returned to normal in the postoperative period, this reversal being possibly associated with the higher granulocyte counts observed in the operative and postoperative periods. However in the present study a depression of chemotactic migration was present in the immediate postoperative period, despite elevation of total leucocyte population. This disparity could have resulted from the timing of blood sampling. In the present study the postoperative blood samples were obtained immediately after completion of anaesthesia and operation, and presumably when there were still varying concentrations of anaesthetic agents present in the body. In contrast, Stanley, et al. ${ }^{6}$ obtained their postoperative blood samples some 60 minutes after the completion of the operation. Thus it would appear that depression observed by both these studies is probably related to adequate concentrations of anaesthetic agents being present in the system at the time of investigation. Since leucocyte chemotaxis is mediated by multiple biochemical mediators, it is possible that other factors associated with surgery such as alterations of temperature, blood $\left[\mathrm{H}^{+}\right]$, systemic arterial oxygen tension, electrolyte and metabolic changes may also influence the magnitude of chemotactic depression. It would appear, however, that any depression of chemotactic migration is transitory in nature and is reversible. Whether this short lived depression of chemotactic migration can contribute towards enhanced incidence of infection, remains to be illucidated.

In the present in vitro investigation of exposure to different concentrations of thiopentone, a dosedependent depression of chemotactic migration similar to that reported in an earlier study ${ }^{4}$ was also observed. These observations are contradictory to those of Duncan and Cullen' and Nunn, et al. ${ }^{8}$ These contradictory findings could have resulted from the differences in methodology used in the different studies. Duncan and Cullen rightly point that the addition of albumin to the system has a protective influence on chemotactic migration in the cells exposed to thiopentone. A similar protective effect due to the addition of albumin was reported in a previous study; ${ }^{4}$ however, a significant inhibitory effect of thiopentone on the leucocyte locomotion was still detected despite the presence of albumin. The present in vitro study tends to support the observations reported previously that thiopentone causes a dose-dependent inhibition of leucocyte locomotion in vitro.

Inhibition or augmentation of the chemotactic response by an agent or a mixture of agents may 
TABLE III

Effects of Thiopentone on Leucocyte Locomorion in Response to Casein, in vilto

\begin{tabular}{|c|c|c|c|c|c|}
\hline \multirow[b]{2}{*}{$\begin{array}{l}\text { Control Migration } \\
(\mu \mathrm{m})(\text { Mean } \pm \text { S.E. })\end{array}$} & \multirow[b]{2}{*}{$\begin{array}{c}\text { Migration to } \\
\text { Casein }(3 \mathrm{mg} / \mathrm{ml})\end{array}$} & \multicolumn{4}{|c|}{ Migration to Casein ( $3 \mathrm{mg} / \mathrm{ml}$ ) in Presence of Thiopentone } \\
\hline & & $\begin{array}{c}10^{-6} \text { Molar } \\
(0.0264 \mu \mathrm{g} / \mathrm{ml}) \\
\text { Mean } \pm \text { S.E. }\end{array}$ & $\begin{array}{c}10^{-5} \text { Molar } \\
(0.264 \mu \mathrm{g} / \mathrm{ml}) \\
\text { Mean } \pm S . E .\end{array}$ & $\begin{array}{r}10^{-5} \text { Molar } \\
(2.64 \mu \mathrm{g} / \mathrm{ml}) \\
\text { Mean } \pm \text { S.E. }\end{array}$ & $\begin{array}{c}10^{-3} \\
(2.64 \mu \mathrm{g} / \mathrm{ml}) \\
\text { Mean } \pm \text { S.E. }\end{array}$ \\
\hline $42.3 \pm 0.62$ & $66.0 \pm 1.24$ & $58.0 \pm 0.91$ & $53.7 \pm 0.51$ & $52.4 \pm 0.47$ & $45.3 \pm 0.29$ \\
\hline $32.0 \pm 0.59$ & $70.6 \pm 0.43$ & $60.6 \pm 0.54$ & $57.1 \pm 0.65$ & $50.7 \pm 0.73$ & $38.8 \pm 0.57$ \\
\hline $28.0 \pm 0.69$ & $56.4 \pm 0.42$ & $48.4 \pm 0.68$ & $43.4 \pm 0.59$ & $39.9 \pm 0.48$ & $33.1 \pm 0.45$ \\
\hline $32.1 \pm 0.78$ & $61.5 \pm 0.54$ & $53.6 \pm 0.63$ & $47.8 \pm 0.62$ & $42.9 \pm 0.67$ & $36.9 \pm 0.43$ \\
\hline $31.1 \pm 0.49$ & $62.8 \pm 0.57$ & $52.9 \pm 0.58$ & $49.8 \pm 0.55$ & $42.5 \pm 0.63$ & $39.2 \pm 0.41$ \\
\hline $32.6 \pm 0.65$ & $69.1 \pm 0.58$ & $53.5 \pm 0.54$ & $50.5 \pm 0.42$ & $48.1 \pm 0.69$ & $41.5 \pm 0.47$ \\
\hline $43.0 \pm 0.63$ & $64.3 \pm 0.63$ & $52.3 \pm 1.34$ & $55.0 \pm 0.36$ & $50.7 \pm 0.39$ & $44.4 \pm 0.65$ \\
\hline $32.6 \pm 0.61$ & $62.8 \pm 0.69$ & $52.1 \pm 0.73$ & $50.8 \pm 0.61$ & $49.9 \pm 0.58$ & $40.6 \pm 0.42$ \\
\hline
\end{tabular}

Thiopentone produced a significant inhibition of chemotactic migration at all concentrations, $(P<0.005)$

occur at several levels. For instance, chemotactic locomotion can be inhibited by interference with energy sources, i.e. oxidative phosphorylation $^{9.10}$ and glycolysis, ${ }^{11.12}$ alterations in cyclic $3^{\prime}$, $5^{\prime}$-adenosine monophosphate (cAMP) ${ }^{13}$, cyclic 3', 5'-guanosine monophosphate (cGMP), and prostaglandins ${ }^{14}$ and inhibition of RNA and protein synthesis. ${ }^{9}$. It is also inhibited by disruption of contractile locomotory systems such as microfilaments ${ }^{15-17}$ and microtubules ${ }^{18-20}$, and membrane stabilising drugs such as steroids $^{12.21,22}$, chloroquine ${ }^{12}$ and local anaesthetic agents. 5

In this complex array of biochemical systems, both anaesthesia and surgical intervention, alone or in combination, may interact at different steps and thus depress the directional chemotactic migration.

The energy requirements for the chemotactically responding neutrophils depend largely on glycolysis and oxidative respiration. Since halothane has been shown to interfere with mitochondrial electron transport mechanisms as well as mitochondrial respiratory control, ${ }^{23}$ it is possible that anaesthesia may also inhibit leucocyte locomotion by interfering with subcellular oxygen utilization. Likewise, oxidation of reduced nicotinamide adenine dinucleotide (NADH) has been shown to be blocked by amytal, ${ }^{24}$ and this could be one of the steps whereby other barbiturates like thiopentone may interfere with leucocyte locomotion which classically requires a dramatic respiratory burst for chemotactic migration.

It has been observed that substances that increase intracellular cyclic AMP levels decrease neutrophil motility. ${ }^{13}$ The effects of anaesthesia and surgery on intracellular cyclic AMP have yet to be investigated in depth. However, Sprague, et al. ${ }^{25}$ have shown that exposure to clinical concentrations of halothane and enflurane resulted in a significant increase in intracellular cyclic AMP in aortic wall tissue of the rat. Thus an anaesthetic induced enhancement of intracellular cAMP could also contribute towards an inhibition of chemotactic migration.

Leucocyte locomotion is microtubule and microfilament dependent. Since anaesthetic agents have been shown to disrupt microtubules, ${ }^{26.27}$ it is conceivable that they may also affect cellular locomotion. However, an effect on microfilaments is more likely, as has been described for fibroblasts treated with local anaesthetics. ${ }^{27}$

Thus it appears that anaesthetic agents may depress chemotactic migration by interfering with a variety of biochemical reactions. However, these anaesthetic-induced defects of leucocyte function appear to be short lived. Whether these short term effects of anaesthesia are significant in terms of enhancing morbidity from latent or active infection is not clear at present. To date most studies have ventured to analyse quantitative defects of leucocyte chemotaxis and further studies are required to evaluate qualitative defects of leucocyte functions which provide the first line of defence against invading organisms.

\section{REFERENCES}

I. Nunn, J.F., Dixon, K.L. \& Moore, J.R. Effect of halothane on Tetrahymena pyriformis. Brit. J. Anaesth., 40: 145, 1968.

2. Nunn, J.F., Sharp, J.A. \& Kimball, K.L. Re- 
versible effects of an inhalational anaesthetic on lymphocyte motility. Nature (Lond.), 226: 85, 1970.

3. Bruce, D.L. Effect of halothane anesthesia on extravascular mobilization of nutrophils. J. Cell Physiol., 68: 81, 1966.

4. Moudgil, G.C., Allan, R.B., Russell, R.J. \& WILKINSON, P.C. Inhibition, by anaesthetic agents, of human leucocyte locomotion towards chemical attractants. Brit. J. Anaesth., 49: 97, 1977.

5. Mathiue, A., Mathiue, D. \& Hyslop, N. Effect of induction agents and non-volatile anesthetics on chemotaxis of polymorphonuclear leucocytes. Anesthesiology, 51-3S: S56, 1979.

6. Stanley, T.H., Hill, G.E., Portas, M.R., HogaN, N.A. \& HILl, H.R. Neutrophil chemotaxis during and after general anesthesia and operating. Anesthesia and Analgesia, 55: 668, 1976.

7. Duncan, P.G., Cullen, B.F. Neutrophil chemotaxis and anaesthesia. Brit. J. Anaesth., 49: 345, 1977.

8. Nunn, J.F., Sturrock, J.E., Jones, A.J. O'Morain, C., Segal, A.W., Coade, S.B., Darling, J., \& WALKER, D. Halothane does not inhibit human neutrophil function in vitro. Brit. J. Anaesth., 51: 1101, 1979.

9. Carruthers, B.M. Leukocyte motility II. Effect of absence of glucose in medium: effect of presence of deoxyglucose, dinitrophenyl, puromycin, actinomycin $D$ and trypsin on the response to chemotactic substance: effect of segregation of cells from chemotactic substance. Canadian J. Physiol. Pharm., 45: 269. 1967.

10. Bryant, R.E., de Prez, R.M., Van Way, M.H. \& Rogers, D.E. Studies on leukocyte motility I. Effects of alterations of $\mathrm{pH}$, electrolyte concentration and phagocytosis on leukocyte migration, adhesiveness and aggregation. J. Exp. Med., 124: 483, 1966.

11. BeCKER, E.L. Biomedical aspects of the polymorphonuclear response to chemotactic factors. In Biochemistry of the Acute Allergic Reactions, edited by K.F. Austen and E.L. Becker. Oxford and Edinburgh: Blackwell. p. 243, 1971a.

12. WARD, P.A. The chemosuppression of chemotaxis. J. Exp. Mental Med., 124: 209, 1966.

13. Tse, R.L., Phelps, P. \& Urban, D. Polymorphonuclear leukocyte motility in vitro, VI. Effect of purine and pyrimidine analogues: Possible role of cyclic AMP. J. Lab. Clin. Med., 80: 264, 1972.
14. Horton, E.W. Hypothesis on physiological roles of prostaglandins. Physiol. Rev., 49: 122, 1969.

15. Becker, E.L., Davis, A.T., Estensen, R.D. \& QuIE, P.G. Cytochalasin B IV. Inhibition and stimulation of chemotaxis of rabbit and human polymorphonuclear leukocytes. J. Immunology, 108: 396, 1972.

16. Malawista, S.E. Cytochalasin B reversibility inhibits phagocytosis by human blood leukocytes. In Progress in Immunology, edited by B. Amos. New York: Academic Press. p. 187, 1971.

17. Zigmond, S.H. \& Hirsch, J.G. Effects of cylochalasin B on polymorphonuclear leucocyte locomotion, phagocytosis and glycolysis. Exp. Cell Res., 73: 383, 1972b.

18. Malawista, S.E. \& Bensch, K.G. Human polymorphonuclear leukocytes: Demonstration of microtubules and effect of colchicine. Sciense, I56: $521,1967$.

19. Bensch, L.G. \& Malawista, S.E. Microtubular crystals in mammalian cells. J. Cell Biology, 40: 95 , 1969.

20. WARD, P.A. Leukotactic factors in health and disease. Am. J. Path., 64: 521, $197 \mathrm{lb}$.

21. Schar, B. \& MeIER, R. Hemmung der durch Proteuslipopolysaccharide gesteigerten Leukozytenemigration in vitro durch antiinflammatorische Corticosteroide. Experientia, 10: 315, 1960.

22. WeISSMAN, G. Labilization and stablization of lysosomes. Fed. Proc., 23: 1083, 1964.

23. Cohen, P.J. \& Marshall, B.E. Effects of halothane on respiratory control and oxygen consumption of rat liver mitochondria. In Toxicity of Anesthetics, edited by B.R. Fink. Baltimore: The Williams and Wilkins Co. p. 34, 1968.

24. ChANCE, B. Structure and function in oxidative phosphorylation. Pharmcol. Rev., 17: 191, 1965.

25. Sprague, D.H., Yang, J.C. \& NGai, S. H. Effects of isoflurane and halothane on contractility and the cyclic $3^{\prime}, 5$ '-adenosine monophosphate system in the rat aorta. Anesthesiology, 40:162-167, 1974.

26. ALLISON, A.C. Effects of inhalational anaesthetics on proteins. In Molecular Mechanisms in General Anaesthesia, edited by M.J. Halsey, R.A. Millar, and J.A. Sutton. Edinburgh: Churchill Livingston. p. $172,1974$.

27. Poste, G., Papahadjopoulos, D. \& Nicoloson, G. Local anesthetics affect transmembrane cytoskeletal control of mobility and distribution of cell surface receptors. Proc. Natl Acad. USA 72: 4430, 1975.

\section{RÉSUMÉ}

La migration chimiotaxique des leucocytes est un des mécanismes précoces essentiels à la défense de l'hôte contre l'infection. On a étudié le retentissement de l'anesthésie et de la chirurgie sur la chimotaxie des leucocytes sur des malades en chirurgie réglée. La migration chimotaxique des leucocytes du sang périphérique observée en utilisant une méthode de Boyden modifiée immédiatement, avant, après la chirurgie et à la deuxième et troisième journée. De plus, l'influence de l'exposition à des concentrations molaires diverses de thiopentone sur la migration chimiotaxique leucocytaire a été observée dans la période postopératoire immédiate $(\mathrm{p}<0.05)$. Cependant, cette inhibition a été de courte durée et l'activité chimiotaxique est revenue à la normale le jour qui a suivi l'intervention sous anesthésie générale. Lors de l'exposition au thiopentone in vitro on a noté une inhibition de la migration chimiotaxique significative et proportionnelle à la dose de l'agent employé. On en a conclu que la chirurgie sous anesthésie générale et l'exposition au thiopentone in vitro produit une inhibition significative bien que réversible de la migration chimiotaxique. 